\title{
GAMBARAN DUKUNGAN SOSIAL MASYARAKAT TERHADAP ORANG DENGAN GANGGUAN JIWA
}

\author{
Syarifah Nurul Fadilla1, Fathra Annis Nauli2*, Erwin ${ }^{3}$ \\ Fakultas Keperawatan \\ Universitas Riau \\ *Email: fathranauli@yahoo.com
}

Diterima : Oktober 2021, Diterbitkan : Desember 2021

\begin{abstract}
Abstrak
Pendahuluan : Dukungan sosial adalah ketersedian, kepedulian dari seseorang yang dapat diandalkan, dukungan sosial ini dapat bersumber dari keluarga dan lingkungan masyarakat. Hal ini dikarenakan ODGJ memerlukan dukungan sosial.Proses pemulihan orang dengan gangguan jiwa tidak terlepas dari peran dan dukungan dari masyarakat. Dukungan sosial masyarkat sangat berpengaruh bagi orang dengan gangguan jiwa daalam menjalani proses penyembuhan dan pengembalian kualitis hidupnya. Tujuan : penelitian ini untuk mengindetifikasikan gambaran dukungan sosial masyarakat terhadap orang dengan gangguan jiwa. Metode : Kuantitatif dengan desain penelitian deskriptif. Penelitian ini dilakukan diwilayah kelurahan selatpanjang selatan dengan jumlah sampel 99 responden. Alat ukur yang digunakan adalah kuesioner sebanyak 17 pertanyaan yang terdiri dari 4 komponen utama yaitu, dukungan emosional, dukungan instrumental, dukungan informasional, dan dukungan penghargaan yang telah di uji validitas $0,448-0,825)$ dan reabilitasnya $(0,848)$. Analisa yang digunakan adalah analisa univariat untuk menggambarkan dukungan sosial masyarakat terhadap orang dengan gangguan jiwa. Hasil : sebagian besar umur responden dewasa akhir (34,3\%), sebagian besar jenis kelamin laki-laki 61 orang $(61,6 \%)$, sebagian besar bekerja 84 orang $(84,8 \%)$, Sebagian besar menikah 79 orang $(79,8 \%)$. Serta didapatkan dukungan sosial masyarakat yang baik yaitu 53 orang (53,5\%). Kesimpulan : Hasil ini disimpulkan bahwa terdapat dukungan sosial baik terhadap orang dengan gangguan jiwa. Hasil penelitian ini menjadi salah satu sumber informasi dalam meningkatkan dukungan sosial masyarakat terhadap orang dengan gangguan jiwa.
\end{abstract}

Kata kunci : Dukungan sosial masyarakat, ODGJ

\begin{abstract}
Introduction : Social support is the availability, caring from someone who can be relied on, this social support can be sourced from family and community. This is because ODGJ need social supportThe process of recovering people with mental disorders cannot be separated from the role and support of the community. Community social support is very influential for people with mental disorders in undergoing the healing process and restoring the quality of their lives. Purpose: This study is to identify the description of social support for people with mental disorders. Method: Quantitative with descriptive research design. This research was conducted in the South Selatpanjang village area with a sample of 99 respondents. The measuring instrument used is a questionnaire with 17 questions consisting of 4 main components, namely, emotional support, instrumental support, informational support, and award support which have been tested for validity and reliability. The analysis used is univariate analysis to describe community social support for people with mental disorders. Results: most of the respondents are late adulthood (34.3\%), most of the sexes are 61 people (61.6\%), most of them work 84 people (84.8\%), Most are married 79 people $(79,8 \%)$. Seta obtained good social support, namely 53 people $(53.5 \%)$. Conclusion: the results of this study can be used as a reference for the community to continue to provide support for people with mental disorders
\end{abstract}

Keywords: Community social support, ODGJ 


\section{PENDAHULUAN}

Undang-undang No. 18 Tahun 2014 tentang kesehatan jiwa menyatakan kesehatan jiwa merupakan suatu kondisi dimana seorang individu dapat berkembang secara fisik, mental, spiritual, dan sosial sehingga individu tersebut menyadari kemampuannya sendiri, dapat mengatasi tekanan, dapat bekerja secara produktif, dan mampu memberikan kontribusi untuk komunitasnya (Kemenkes RI, 2014). Tidak berkembangnya koping individu dengan baik dapat menyebabkan terjadinya gangguan jiwa (Sulistiyowati, 2015). Gangguan jiwa merupakan gangguan yang terjadi pada fungsi mental yang meliputi, pikiran perilaku, perasaan, motivasi, kemauan, keinginan dan persepsi sehingga mengganggu dalam proses hidup di masyarakat (Nasir \& Muhith, 2015).

Saat ini data jumlah gangguan jiwa cukup mengkhawatirkan, berdasarkan penelitian yang dilakukan oleh Ayuningtyas, Misnaliarti dan Rayhani (2018) dengan judul analisis situasi kesehatan mental pada masyarakat di Indonesia dan strategi penanggulangannya, menunjukkan bahwa masih banyak kasus gangguan kesehatan mental pada masyarakat Indonesia, hingga saat ini orang dengan gangguan jiwa masih mengalami penanggalan serta perlakuan yang salah. Pada tingkat global, lebih dari 300 juta orang diperkirakan menderita depresi, setara dengan $4,4 \%$ dari populasi dunia, gangguan mental global akan meningkat khususnya di negara-negara berpenghasilan rendah, karena populasinya yang terus bertambah (WHO, 2017). Peningkatan gangguan jiwa yang terjadi saat ini akan menimbulkan masalah baru yang disebabkan adanya ketidakmampuan serta gejala yang ditimbulkan oleh penderita gangguan jiwa tersebut (Badan Penelitian dan Pengembangan Kesehatan, 2013).

Data dari Dinas Kesehatan Kabupaten Kepulauan Meranti dari bulan Januari sampai bulan Desember tahun 2019 menunjukkan bahwa jumlah kasus penderita gangguan jiwa di wilayah
Puskesmas se-Kabupaten Kepulauan Meranti yang berjumlah 10 Puskesmas terdapat 346 penderita orang dengan gangguan jiwa. Jumlah orang dengan gangguan jiwa di wilayah kerja Puskesmas Alah Air berjumlah 69 orang dan yang terendah terdapat di wilayah kerja Puskesmas Sungai Tohor dengan jumlah 15 orang (Dinkes, 2019). Kasus terbanyak terdapat di Puskesmas Alah Air adalah skizofrenia yaitu sebanyak 60 orang.

Gangguan jiwa menimbulkan kerugian ekonomi mencapai Rp 20 triliun, akibat hilangnya produktivitas, beban ekonomi dan biaya perawatan kesehatan yang harus ditanggung keluarga dan negara. Klien gangguan jiwa tidak hanya membutuhkan dukungan ekonomi saja tetapi juga memerlukan sistem dukungan sosial yang mencakup dukungan emosional, informasional, instrumental dan penilaian atau penghargaan untuk menjalani program pemulihan (recovery) dan menghadapi anggapan negatif dari masyarakat (Asmadi, 2012).

Dukungan sosial adalah ketersedian, kepedulian dari seseorang yang dapat diandalkan (Karangora, 2012). Penelitian yang dilakukan oleh Nur dan Shanti (2011) menyatakan bahwa dukungan sosial yang didapatkan oleh individu dari lingkungan sekitar baik itu dari keluarga maupun masyarakat sekitarnya, akan mempengaruhi cara individu tersebut dalam menghadapi stress dan kecemasan dalam menjalani kehidupan. Individu yang menerima dukungan sosial dari individu lain akan merasa dirinya dicintai, dihargai, dan merasa bahwa dirinya merupakan bagian dari lingkungan sosialnya (Laswari, 2017).

Seseorang individu yang memiliki dukungan sosial yang tinggi mempunyai tingkat stres yang rendah, lebih berhasil mengatasi dan mengalami hal-hal positif dalam hidup dengan lebih baik (Taylor, 2015). Dukungan sosial yang diberikan berupa dukungan emosional, informasional, instrumental, dan 
penghargaan yang dapat memfasilitasi proses beradaptasi dan meningkatkan peran fungsi sehingga akan memulihkan orang-orang yang mengalami gangguan jiwa (Davis \& Brekke, 2014).

Dukungan sosial masyarakat diperlukan untuk pemulihan gangguan jiwa dengan memberikan dukungan secara psikologis (Maulana, 2016). Orang dengan gangguan jiwa merasa rendah diri ketika kembali menjalani hidup di masyarakat pasca perawatan di rumah sakit jiwa, hal ini dikarenakan masih terbentuknya stigma negatif terkait orang penderita gangguan jiwa serta tidak ada dukungan penuh dari pihak terkait. Menurut Repper (2011) masyarakat harus terlibat dalam kesembuhan penderita gangguan jiwa dengan memberikan dukungan sosial terutama untuk tempat tinggal yang aman dan lingkungan yang mendukung.

Dukungan sosial adalah salah satu faktor yang dapat membantu menurunkan angka kekambuhan, maka penting bagi masyarakat untuk memberikan dukungan sosial bagi penderita gangguan jiwa (Kemenkes RI, 2014). Efek yang menguntungkan dari dukungan sosial dapat muncul baik melalui interaksi individu dengan lingkungan sekitarnya ataupun representasi sosial psikologis individu sebagai sumber untuk melawan stres dan dapat memenuhi kebutuhan dasar individu tersebut (Gottleib, 2009 dalam Laswari, 2017). Dukungan yang sesuai akan sangat membantu individu untuk memenuhi kebutuhan saat mengalami kondisi yang sulit, individu yang dapat menemukan cara yang efektif untuk keluar dari masalah, merasa dirinya dihargai dan dicintai yang akan meningkatkan kepercayaan pada dirinya untuk mampu menjalani kehidupan dengan lebih baik. Akan tetapi ketika individu tidak melihat bantuan sebagai dukungan, dan dukungan yang diberikan tidak sesuai, maka kecil kemungkinan individu dapat mengurangi stress (Sarafino, 2011).

Studi pendahuluan dilakukan oleh peneliti pada tanggal 20 Juni 2020 kepada
11 orang warga di wilayah kerja Puskesmas Alah Air dengan metode wawancara mengenai dukungan masyarakat terhadap orang dengan gangguan jiwa. Hasil studi pendahuluan yang dilakukan pada tanggal 20 Juni 2020 mengenai dukungan masyarakat terhadap orang dengan gangguan jiwa menunjukkan bahwa 6 warga mengatakan bahwa tidak pernah memberikan dukungan dalam bentuk apapun terhadap orang dengan gangguan jiwa baik dukungan sosial emosional, dukungan sosial informasional, dukungan penghargaan dan dukungan instrumental.

Dukungan sosial emosional seperti tidak pernah peduli terhadap keadaan dan perasaan ODGJ, dukungan sosial informasional seperti tidak bersedia memberikan informasi kesehatan kepada orang dengan gangguan jiwa, dukungan penghargaan seperti menerima kehadiran orang dengan gangguan jiwa, dan dukungan instrumental seperti memberikan bantuan seperti uang kepada orang dengan gangguan jiwa. Hal ini dikarenakan warga merasa takut jika mendekati orang dengan gangguan jiwa yang dapat melukai kapan saja, 5 dari 11 warga mengatakan bahwa pernah memberikan makanan kepada orang dengan gangguan jiwa, memberikan pakaian, menjenguk orang dengan gangguan jiwa dan warga juga mengatakan orang dengan gangguan jiwa juga perlu untuk diperhatikan, dan tidak boleh dijauhi karena penderita juga memiliki hak untuk mendapatkan perlakukan yang baik dari keluarga maupun lingkungannya agar proses penyembuhan dapat berjalan dengan sebagaimana mestinya.

Hasil wawancara bersama seorang kader jiwa mengatakan bahwa program kesehatan jiwa yang dilakukan oleh kader dan petugas kesehatan yaitu berbentuk Home Care yang dilakukan setiap satu sampai dengan dua kali dalam satu bulan guna untuk memeriksa kondisi orang dengan gangguan jiwa tersebut dan sekaligus memberikan pendidikan kesehatan kepada masyarakat sekitar untuk 
tidak menjauhi ataupun bersikap diskriminatif kepada orang dengan gangguan jiwa, namun kader jiwa mengatakan tetap masih ada beberapa orang warga yang masih mengeluh karena merasa resah jika orang dengan gangguan jiwa tersebut mengganggu masyarakat yang ada dilingkungannya.

Hasil studi pendahuluan yang telah peneliti lakukan didapatkan bahwa warga di Kelurahan Selatpanjang Selatan memiliki perbedaan dukungan baik dan kurang terhadap orang dengan gangguan jiwa, maka dari fenomena tersebut peneliti tertarik untuk melakukan penelitian dengan judul "Gambaran Dukungan Sosial Masyarakat terhadap Orang dengan Gangguan Jiwa”.

\section{METODE}

Desain dalam penelitian yang digunakan dalam penelitian ini adalah deskriptif. Metode ini digunakan untuk mendeskripsikan karakteristik tertentu, menggunakan angka dengan analisis univariat. Pada penelitian ini, peneliti melakukan pengisian lembar kuesioner untuk memperoleh informasi tentang gambaran dukungan sosial masyarakat terhadap orang dengan gangguan jiwa (ODGJ).

Lokasi penelitian ini di lakukan di Kelurahan Selatpanjang Selatan, khususnya penelitian ini dilakukan di RT 1 RW 1, RT 4 RW 3, RT 3 RW 5, RT 2 RW 6, RT 5 RW 4, RT 1 RW 9, dan RT 2 RW 10 dengan jumlah keseluruhan 7 RW. Kegiatan penelitian ini dimulai dari persiapan yaitu pengajuan proposal pada bulan Maret hingga seminar hasil Agustus 2021.

Teknik pengambilan sampel pada penelitian ini menggunakan Teknik Simple random sampling dikatakan simple (sederhana) karena pengambilan anggota sampel dari populasi dilakukan secara acak tanpa memperhatikan strata yang ada dalam populasi itu (Sugiyono, 2011). Jumlah sampel dari penelitian ini dapat diambil dengan menggunakan rumus
Slovin. Alat pengumpul data pada penelitin ini mengggunakan kuesioner. Kemudian peneliti melakukan modifikasi kuesioner dari penelitian Laswari (2017) sebagai acuan untuk membuat pertanyaan dalam kuesioner.

Kuesioner ini terdiri dari 4 komponen yaitu dukungan emosional, dukungan informasional, dukungan instrumental, dan dukungan penghargaan serta terdapat pembagian pertanyaan positif dan negatif. Kuesioner ini terdiri dari 17 pertanyaan dengan hasil ukur berupa baik $>50$ dan kurang $<50$ dan menggunakan skala likert. Kuesioner ini telah dilakukan uji validitas $(0,448-0,825)$ dan reabilitasnya $(0,848)$.

\section{HASIL DAN PEMBAHASAN}

Hasil penelitian tentang gambaran dukungan sosial masyarkat terhadap orang dengan gangguan jiwa di wilayah Kelurahan Selatpanjang Selatan pada tanggal 29 Maret 2021 sampai 2 April 2021 dengan responden sebanyak 99 orang adalah sebagai berikut:

\section{A. Karakterisitk Umur}

Tabel 1. Karakteristik Umur Responden

\begin{tabular}{lcc}
\hline $\begin{array}{c}\text { Karakteristik } \\
\text { responden }\end{array}$ & Frekuensi & $\begin{array}{c}\text { Presentasi } \\
(\%)\end{array}$ \\
\hline $\begin{array}{l}\text { Remaja akhir } \\
(18-25)\end{array}$ & 3 & 3,0 \\
$\begin{array}{l}\text { Dewasa awal } \\
(26-35)\end{array}$ & 23 & 23,2 \\
$\begin{array}{l}\text { Dewasa akhir } \\
(36-45)\end{array}$ & 38 & 34,3 \\
$\begin{array}{l}\text { Lansia awal } \\
(46-55)\end{array}$ & 34 & 38,4 \\
$\begin{array}{l}\text { Lansia akhir } \\
(56-65)\end{array}$ & 1 & 1,0 \\
\hline Jumlah & 99 & 100 \\
\hline
\end{tabular}

Sebagain besar umur responden berada pada rentang dewasa akhir (3545 tahun) yang berjumlah 38 responden $(38,4 \%)$. Usia diartikan dengan lamanya keberadaan seseorang yang terhitung pada saat individu tersebut dilahirkan (Notoadtmojo, 2010).

Menurut Notoadtmojo (2010) perbedaan usia juga mempengaruhi 
pola pikir dari masyarakat, umur juga merupakan tingkat kedewasaan seseorang maka pengetahuan merekapun bertambah bukan hanya berasal dari lingkungan tetapi pengalaman mereka dalam menghadapi realita kematangan pemikiran. Berdasarkan Potter dan Perry (2010) dimana kategori umur berhubungan dengan usia kerja, kekuatan fisik dan kecerdasan intelektual maupun emosional. Kemampuan seseorang dalam berfikir kritis dan menyampaikan pendapat selama usia dewasa berdasarkan pengalaman yang diperoleh selama ini. Penelitian ini juga sejalan dengan penelitian Nursalam (2008), yang menyatakan bahwa tingkat kematangan dan kekuatan akan lebih matang dalam kehidupan sehari-hari, dan tingkat kematangan dalam berpikir juga dipengaruhi oleh pengalaman.

\section{B. Karakteristik Jenis Kelamin}

Tabel 2. Karakteristik Jenis Kelamin Responden

\begin{tabular}{lcc}
\hline $\begin{array}{c}\text { Karakteristik } \\
\text { responden }\end{array}$ & Frekuensi & $\begin{array}{c}\text { Presentasi } \\
(\%)\end{array}$ \\
\hline Laki-laki & 61 & 61,6 \\
Perempuan & 38 & 38,4 \\
\hline Jumlah & 99 & 100 \\
\hline Hasil & penelitian & didapatkan
\end{tabular}

bahwa 61 orang responden $(61,6 \%)$ berjenis kelamin laki-laki sedangkan responden perempuan berjumlah 38 orang $(38,4 \%)$. Hal ini sejalan dengan Arifin dan Zainal (2011) yang mengatakan bahwa karakteristik seseorang seperti jenis kelamin dapat mempengaruhi seseorang dalam memberikan interpretasi persepsi pada suatu objek atau stimulus yang dilihanya dan pebedaan jenis kelamin cenderung membentuk persepsi yang berbeda antara laki-laki dan perempuan dalam menilai suatu objek. Pada saat peneliti melakukan penelitian, peneliti lebih banyak menemui responden laki laki daripada perempuan.
Penelitian ini sejalan dengan penelitian Sharma, Chakrabarti, dan Grover, (2016) yang mengatakan bahwa laki-laki memiliki kemampuan memberikan dukungan yang lebih luas dari pada wanita, hal ini dikarenakan laki-laki dapat menggunakan strategi coping yang lebih efektif seperti memberikan problem solving yang lebih baik.

C. Karakteristik Status Pekerjaan

Tabel 3. Karakteristik Status Pekerjaan Responden

\begin{tabular}{lcc}
\hline $\begin{array}{c}\text { Karakteristik } \\
\text { responden }\end{array}$ & Frekuensi & $\begin{array}{c}\text { Presentasi } \\
(\%)\end{array}$ \\
\hline Bekerja & 84 & 84,8 \\
Perempuan & 15 & 15,2 \\
\hline Jumlah & 99 & 100 \\
\hline
\end{tabular}

Hasil penelitian ini didapatkan bahwa responden sebagian besar bekerja yaitu 84 orang $(84,8 \%)$. Foster (2008 dalam Laswari 2017) mengatakan bahwa lingkungan pekerjaan dapat menjadikan seseorang memperoleh pengalaman dan pengetahuan yang baik secara langusung ataupun tidak langsung. Pekerjaan merupakan faktor yang sangat mempengaruhi masyarakat dalam berpresepsi ataupun dalam memberikan dukungan terhadap orang dengan gangguan jiwa.

Penelitian ini sejalan dengan Notoadtmojo (2010) juga mengatakan bahwa pekerjaan merupakan faktor yang mempengaruhi persepsi maupun sikap seseorang. Ditinjau dari seseorang yang sering berinteraksi dengan orang lain lebih banyak pengetahuannya bila dibandingkan dengan orang tanpa ada interaksi dengan orang lain. Pengalaman belajar dalam bekerja yang dikembangkan memberikan pengetahuan dan keterampilan profesional serta pengalaman belajar dalam bekerja akan dapat mengembangkan kemampuan dalam mengambil keputusan yang merupakan keterpaduan menalar secara ilmiah dan etik. 
Penelitian ini juga sejalan dengan penelitian Syarniah, Rizani, dan Sirait (2014) yang mengatakan bahwa masyarakat yang bekerja mempunyai persepsi yang positif terhadap ODGJ. Masyarakat yang bekerja tentu lebih terpapar dengan lingkungan luar yang lebih luas dan pendidikan yang tinggi. Situasi ini mendukung untuk peningkatan informasi yang positif. Masyarakat yang bekerja memiliki cukup informasi tentang konsep pada penanganan ODGJ di masyarakat, tidak mengucilkan, dan memiliki antusiasme untuk memberikan penatalaksanaan yang lebih tepat, yaitu melaporkan dan merujuk ODGJ ke pusat layanan kesehatan terdekat. Situasi dan kondisi ini tentu dapat mempengaruhi informasi dan kemampuan persepi seseorang yang dapat menghasilkan persepsi yang lebih terhadap ODGJ.

D. Karakteristik Status Pernikahan

Tabel 4. Karakteristik Status Pernikahan Responden

\begin{tabular}{lcc}
\hline $\begin{array}{c}\text { Karakteristik } \\
\text { responden }\end{array}$ & Frekuensi & $\begin{array}{c}\text { Presentasi } \\
(\%)\end{array}$ \\
\hline Menikah & 79 & 79,8 \\
Belum & 19 & 19,2 \\
Menikah & & \\
\hline Jumlah & 99 & 100 \\
\hline
\end{tabular}

Hasil penelitian ini didapatkan bahwa responden sebagian besar menikah yaitu 79 orang $(79,8 \%)$. Pernikahan merupakan tahapan perkembangaan dalam kehidupan seseorang yang memberikan perasaan membahagiakan seperti perasaan dimiliki, dilindungi, memberi rasa aman serta mendapatkan dukungan dari orang lain (Olson \& Defrain, 2006). Individu yang sudah menikah cenderung dapat mengubah persepsi yang timbul dilingkungannya, dengan adanya dukungan sosial yang tinggi maka akan mengurangi potensi terjadinya perbedaan pendapat. Penelitian ini sejalan dengan penelitian Sarafino (2011) yang mengatakan bahwa dukungan dari individu yang memiliki pasangan dapat diwujudkan dari beberapa bentuk antara lain dukungan emosi yaitu menggunakan perkataan yang baik dan lembut.

E. Gambaran Dukungan Sosial Masyarakat

Tabel 5

Distribusi Frekuensi Dukungan Sosial Masyarakat yang Didapatkan dari Responden

\begin{tabular}{lllccc}
\hline \multirow{2}{*}{ No } & \multirow{2}{*}{$\begin{array}{c}\text { Kategori } \\
\text { Dukungan }\end{array}$} & \multicolumn{2}{c}{ Baik } & \multicolumn{2}{c}{ Kurang } \\
\cline { 2 - 4 } & $\mathrm{N}$ & $\%$ & $\mathrm{~N}$ & $\%$ \\
\hline 1 & $\begin{array}{l}\text { Dukungan } \\
\text { emosional }\end{array}$ & 65 & 65,7 & 34 & 34,3 \\
\hline 2 & $\begin{array}{l}\text { Dukungan } \\
\text { instrumental }\end{array}$ & 65 & 65,7 & 34 & 34,3 \\
\hline 3 & $\begin{array}{l}\text { Dukungan } \\
\text { informasional }\end{array}$ & 78 & 78,8 & 21 & 21,2 \\
\hline 4 & $\begin{array}{l}\text { Dukungan } \\
\text { penghargaan }\end{array}$ & 80 & 80,8 & 19 & 19,2 \\
\hline
\end{tabular}

Berdasarkan tabel 5 diketahui dukungan emosional sebanyak 65 orang $(65,7 \%)$, dukungan instrumental 65 orang $(65,7 \%)$, dukungan informasional 78 orang $(78,8 \%)$, dan dukungan penghargaan 80 orang $(80,8 \%)$.

\section{F. Dukungan Sosial Masyarakat}

Tabel 6

Distribusi Frekuensi Dukungan Sosial Masyarakat yang Didapatkan Responden ( $\mathrm{n}=99$ )

\begin{tabular}{llcc}
\hline No. & $\begin{array}{c}\text { Dukungan sosial } \\
\text { masyarakat }\end{array}$ & F & $\%$ \\
\hline 1. & Baik & 53 & 53,5 \\
2. & Kurang & 46 & 46,6 \\
\hline & Jumlah & 99 & 100 \\
\hline & Tabel 6 menunjukkan & bahwa
\end{tabular}
responden yang memiliki dukungan sosial masyarakat baik sebanyak 53 responden $(53,5 \%)$ dan dukungan sosial masyarakat kurang sebanyak 46 responden $(46,6 \%)$.

Berdasarkan penelitian yang dilakukan pada 99 orang responden dari setiap perwakilan keluarga menunjukkan bahwa Sebagian besar masyarakat memiliki dukungan baik yaitu sebanak 53 orang (53,5\%). Taylor (2015) mengatakan bahwa Dukungan sosial masyarakat adalah suatu bentuk sokongan atau dukungan yang diberikan 
oleh orang-orang yang ada dilingkungan tempat tinggal baik itu tetangga, kelompok masyarakat, atau tokoh masyarakat untuk meningkatkan sumber koping individu, dan membantu dalam penyesuaian psikologis terhadap suatu masalah atau penyakit untuk mencegah stress. Penelitian yang dilakukan oleh Maulana (2016) mengatakan dukungan sosial masyarakat diperlukan untuk pemulihan gangguan jiwa dengan memberikan dukungan secara psikologis. Orang dengan gangguan jiwa merasa rendah diri ketika kembali menjalani hidup dimasyarakat pasca perawatan di rumah sakit jiwa. Menurut Repper (2011) masyarakat harus terlibat dalam kesembuhan penderita gangguan jiwa dengan memberikan dukungan sosial terutama untuk tempat tinggal yang aman dan lingkungan yang mendukung. Hal ini sejalan dengan penelitian yang dilakukan oleh Sulistyorini, Widodo, dan Zulaicha (2013) mengungkapkan bahwa sikap masyarakat dalam kategori mendukung atau positif, mayoritas masyarakat berpendapat bahwa orang dengan gangguan jiwa sama seperti manusia biasa yang berhak hidup normal seperti orang-orang yang sehat kejiwaannya, jadi kalau ada tetangga yang mengalami gangguan jiwa masyarakat mengatakan sebaiknya segera diobati atau dirawat di Rumah Sakit Jiwa. Apabila keluarga yang mempunyai orang dengan gangguan jiwa tidak mampu secara ekonomi untuk mengobati masyarakat berpendapat untuk menyarankan agar meminta bantuan kepada pemerintah desa setempat untuk pengobatannya. Karena jika orang gangguan jiwa sudah parah maka akan membahayakan dan akan mengganggu kenyamanan warga setempat. Apabila orang gangguan jiwa berbahaya maka yang harus dilakukan adalah mengamankannya.

Hal ini juga diperkuat dengan teori Bedaso, et al (2016) yang mengatakan bahwa peran dan dukungan masyarakat terhadap orang dengan gangguan jiwa sangatlah penting sebagai penguat bagi penderita gangguan jiwa, sebagai pencehagan kekambuhan, dan dalam mencari pengobatan, kepatuhan obat dan rehabilitasi.

\section{SIMPULAN}

Hasil penelitian yang dilakukan kepada 99 orang responden masyarkat di wilayah Kelurahan Selatpanjang Selatan dapat disimpulkan bahwa sebagian besar responden berumur 35-45 tahun sebanyak $(38,4 \%)$ dengan jenis kelamin terbanyak pada laki-laki yaitu 61 orang $(61,6 \%)$. Sebagian besar responden bekerja yaitu sebanyak 84 orang $(84,8 \%)$ dan responden yang sudah menikah sebanyak 79 orang $(79,8 \%)$.

Hasil penelitian menunjukkan bahwa dukungan masyarakat sebanyak 53 orang $(53,5 \%)$, dukungan emosional yang baik 65 orang $(65,7 \%)$, dukungan informasional yang baik 78 orang $(78,8 \%)$, dukungan instrumental yang baik 65 orang $(65,7 \%)$, dan dukungan penghargaan yang baik 80 orang $(80,8 \%)$.

Berdasarkan penelitian dapat disarankan yaitu dengan hasil penelitian ini hendaknya senantiasa dapat berkembang kelimuannya dan menjadi sumber informasi terkait dukungan sosial masyarakat terhadap orang dengan gangguan jiwa

\section{UCAPAN TERIMAKASIH}

Peneliti mengucapkan terima kasih kepada Kelurahan Selatpanjang Selatan yang sudah memberikan kesempatan untuk melakukan penelitian dilokasi tersebut sehingga saya dapat menyelesaikan skripsi ini.

\section{DAFTAR PUSTAKA}

Arifin, \& Zainal. (2011). Penelitian pendidikan metode dan paradigma baru. Bandung: Remaja Rosda Karya.

Asmadi. (2012). Gangguan Jiwa di Indonesia Masih Terabaikan. Jakarta: Salemba Medika.

Ayuningtyas, D., Misnaliarti, N., \& Rayhani, M. (2018). Analisa situasi 
kesehatan mental pada masyarakat di Indonesia dan strategi penanggulangannya. Jurnal Ilmu Kesehatan Masyarakat, 9(1), 1-10.

Badan Penelitian dan Pengembangan Kesehatan. Data Riset Kesehatan Dasar Tahun 2013. Jakarta: Kementerian Kesehatan

Bedaso , A., Yeneabat, T., Yohannis , Z., Bedasso , K., \& Feyera, F. (2016). Community Attitude and Associated Factors towards People with Mental Illness among Residents of Worabe Town, Silte Zone, Southern Nation's Nationalities and People's Region, Ethiopia. PLoS One, 11(3), 1-12.

Davis, L., \& Brekke, J. (2014). Social support and functional outcome in severe mental illness: the mediating role of proactive coping. Psychiatry Research, 215(1), 39-45.

Dinas Kesehatan Kabupaten Kepulauan Meranti. (2019). Jumlah kasus gangguan jiwa di Kabupaten Kepulauan Meranti, JanuariDesember. Kabupaten Kepulauan Meranti: Dinas Kesehatan Kabupaten Kepulauan Meranti

Karangora. (2012). Hubungan Antara Dukungan Sosial Dan Kualitas Hidup Pada Lesbian Di Surabaya. Jurnal Ilmiah Mahasiswa Surabaya, 1(1), 1-9.

Kementerian Kesehatan Republik Indonesia. (2014). Undang-undang Republik Indonesia nomor 18 tahun 2014 tentang kesehatan jiwa. Diperoleh pada tanggal 20 Januari 2020 dari http//binfar.kemkes.go.id

Laswari, t. (2017). Hubungan dukungan sosial keluarga dan masyarakat terhadap kekambuhan pasien skizofrenia. Pekanbaru: UNRI Press.

Maulana. (2016). Peringati hari kesehatan jiwa sedunia, magister keperawatan unpad sosialisasikan upaya pemulihan penderita gangguan jiwa. Padjajaran: Universitas Padjajaran.

Nasir, \& Muhith. (2015). Dasar-dasar keperawatan jiwa pengantar dan teori. Jakarta: Salemba Medika.

Notoadtmojo. (2010). Ilmu Perilaku Kesehatan. Jakarta: Rhineka Cipta.

Nur, A. L., \& Shanti, L. P. (2011). Kesepian pada narapidana di Lembaga Pemasyarakatan Kedungpane Semarang ditinjau dari status sosial dan perkawinan. Jurnal Psikologi, 4(2), 67-79.

Olson, D. H., \& Defrain. (2006). Marriages and Families: Intimacy defercity and strengths. New York: McGraw-Hill.

Potter, \& Perry. (2010). Fundamental Keperawatan. Jakarta: EGC.

Repper. (2011). A review of the literature on peer support mental health services. Jurnal of Mental Health Informa Health Care, 20(4), 392-411.

Sarafino. (2011). Health Psychology: Biopsychosocial 7Th Edition. United States of America: John Wiley \& Sons Inc.

Sharma, N., Chakrabarti, S., \& Grover, S. (2016). Gender differences in caregiving among family caregivers of people with mental illnesses. World J Psychiatry, 6(1), 7-17.

Sugiyono. (2011). Metode penelitian kuantitatif dan kualitatif. Bandung: Alfabeta.

Sulistiyowati. (2015). Pengaruh Terapi Family Psychoeducation terhadap kemampuan Keluarga merawat anggota keluarga dengan gangguan 
jiwa. Community of Publishing In Nursing, 3(1), 1-7.

Sulistyorini, N., Widodo, A., \& Zulaicha, E. (2013). Hubungan pengetahuan tentang gangguan jiwa terhadap sikap masyarakat kepada penderita gangguan jiwa di Wilayah kerja Puskesmas Colomadu I (Doctoral Disertation) . Surakarta: Universitas Muhammadiyah Surakarta.

Syarniah, Rizani, A., \& Sirait , E. (2014). Studi Deskriptif Persepsi Masyarakat Tentang Pasung Pada Klien Gangguan Jiwa Berdasarkan Karakteristik Demografi Di Desa Sungai Arpat Kecamatan Karang Intankabupaten Banjar. Jurnal Skala Kesehatan, 5(2), 1-9.
Taylor. (2015). Health Psycology. New York: McGraw-Hill Education.

World Health Organization. (2017). Depression and other common mental disorder. Diperoleh tanggal 23 Januari 2020 dari https://apps.who.int 